\title{
A Needs Analysis in Teaching ESP Writing at Igor Sikorsky Kyiv Polytechnic Institute
}

\author{
S. S. Kolomiets ${ }^{1}$, O. V. Tsepkalo ${ }^{2, *}$, I. I. Antonenko ${ }^{3}$ \\ ${ }^{1}$ Department of Theory, Practice and Translation of English, Faculty of Linguistics, National Technical University of Ukraine 'Igor \\ Sikorsky Kyiv Polytechnic Institute', Kyiv, 03056, Ukraine \\ ${ }^{2}$ Department of English for Engineering No. 2, Faculty of Linguistics, National Technical University of Ukraine 'Igor Sikorsky Kyiv \\ Polytechnic Institute', Kyiv, 03056, Ukraine \\ ${ }^{3}$ Department of English for Humanities No. 3, Faculty of Linguistics, National Technical University of Ukraine 'Igor Sikorsky Kyiv \\ Polytechnic Institute', Kyiv, 03056, Ukraine
}

Received March 15, 2020; Revised October 10, 2020; Accepted October 24, 2020

\section{Cite This Paper in the following Citation Styles}

(a): [1] S. S. Kolomiets, O. V. Tsepkalo, I. I. Antonenko, "A Needs Analysis in Teaching ESP Writing at Igor Sikorsky Kyiv Polytechnic Institute," Universal Journal of Educational Research, Vol. 8, No. 12, pp. 6361-6368, 2020. DOI: 10.13189/ujer.2020.081201.

(b): S. S. Kolomiets, O. V. Tsepkalo, I. I. Antonenko (2020). A Needs Analysis in Teaching ESP Writing at Igor Sikorsky Kyiv Polytechnic Institute. Universal Journal of Educational Research, 8(12), 6361-6368. DOI: 10.13189/ujer.2020.081201.

Copyright $\bigcirc 2020$ by authors, all rights reserved. Authors agree that this article remains permanently open access under the terms of the Creative Commons Attribution License 4.0 International License

\begin{abstract}
The present study aims at considering a questionnaire as an instrument of needs analysis in teaching English for special purposes (ESP). One of key factors in implementing market oriented changes into educational process lies in specifying both employers' and students' needs in teaching ESP. A needs analysis in the form of questionnaires is used to identify the most needed abilities in oral and written specialism oriented communication in English, thus, contributing to determining the content of learning. In National ESP Curriculum, the content covers professional and academic content; situational content (the context within which the materials, activities, etc., are presented); and pragmatic content (necessary practical and useful skills). It also takes into account students' backgrounds and their study and target needs. The content selection for ESP syllabi is specified by questionnaires for university students, young professionals, ESP and subject teachers, administrators. The paper focuses on the surveys conducted in the Institute of Publishing and Printing and the Faculty of Chemical Engineering with the aim to gather information about students' needs in learning written specialism-oriented writing. Examining studies in the field of ESP in general and needs analysis in particular was accepted as the theoretical basis of the study. The research results show that questionnaires are effective tools in specifying the
\end{abstract}

content of learning, defining students' motives in learning written communication. The interpretation of the survey helped to improve the process of teaching and learning outcomes. The findings suggest that students' feedback in the form of answering the questions of questionnaires should be regular practice in the process of teaching. It became clear that writing and using questionnaires as well as analyzing and interpreting their results require special knowledge and skills and should be implemented in the process of developing writing skills in ESP teaching.

Keywords Questionnaire, Survey, English for Special Purposes, ESP, Needs Analysis, NA, Writing Skills

\section{Introduction}

In Ukraine for years at all levels, the need in an innovative direction of the state development is considered to be the most urgent task has been discussing. The necessary laws have been adopted, programs approved, technology transfer centers and business incubators established, regular trainings and roundtables, as well as competitions of innovative ideas, have been conducting.

It should be stated that in European and American 
education the educational policy has for a long time been understood in terms of interconnection of educational planning and marketing. The statement that students are 'clients' or 'consumers' and courses are 'programs of study' was issued as far as in 1995 [1].

In Ukraine despite the evident changes in educational policy over the past decades accepting the market economy laws in terms of higher education remains one of the most urgent challenges. In some of Ukraine's universities the changes caused by the Bologna process are mostly cosmetic and as C. King stated both individuals and institutions who are keeping a low profile, hoping that it will all go away and that university life will return to 'normal' [Ibid].

At the same time the strategy of Ukraine's research-type universities, which accepted the model of training future specialists, based on the 'Education - Science - Innovation' trilogy, is to train specialists with the developed strategies for innovative activities.

A new model for organizing the innovation process called 'Triple Helix' was proposed by H. Etzkowitz more than 10 years ago. It is based on three factors, namely, university, industrial sector and the innovative development of the state. According to this model the university itself is the main center of innovation [2].

In a research-type university, the entire educational process is defined as learning, science, and innovation, so the university becomes a major hub for public efforts and resources to develop innovation. The academic component of a research-type university remains unchanged, and it operates in three interrelated areas - training, research, innovations and their launch (technological transfer). The mentioned above model has been successfully implemented in Igor Sikorsky KPI.

The 'Sikorsky Challenge' startup contest is as a vivid illustration of this application. It is reckoned to be creative work with a new idea; searching for a formerly unused business model for an innovative idea that is able to bring certain revenues in the future. A startup environment is a creative environment where researchers implement their ideas and developments getting support through training and communication. The first Innovation Ecosystem in Ukraine 'Sikorsky Challenge' has specifically been created to involve creative students in innovative entrepreneurship. Here, technological ideas are grown, innovative startup companies are launched and developed. This is the environment in which the full technological circle is carried out - from searching for new ideas and designing business models to attracting investments and creating new innovative. The role of foreign languages in the implementing the model for organizing the innovation process at the technical university cannot be overestimated.

Ukraine's integration into the world's information space and its signing the Bologna Agreement have led to rethinking of the education aims and content. Over the past decades significant development in teaching ESP in
Ukrainian universities has been observed.

This is evidenced from the numerous researches both in Ukraine and all over the world [5], [6], [7], [8], [9], [10] but they do not exhaust all the issues of professional training of students of higher educational institutions and do not reveal all the problems of foreign language training. Analysis of the literature shows that teaching English, especially English for specific purposes (ESP) at universities has received a lot of attention from teachers and students. ESP instruction is aimed at training qualified professionals and requires special language programs which focus on students' special needs. Many scientific works are devoted to the questionnaire during the methodological researches. The findings in the literature have shown that research methods play an important role in obtaining scientific data on the effectiveness of educational materials, methods and forms of the educational process [11].

Nowadays students learn ESP to develop the ability to use a foreign language as the main means in communicating and cooperating with foreign partners in the professional field situations.

Teaching ESP has been seen as a separate activity for teaching and it has developed its own methodology and its research which draws on [9]. T. Dudley-Evans [10] determined absolute characteristics of ESP. ESP is designed to meet specific needs of the learner and makes use of the underlying methodology and activities of the disciplines. According to C. Tribble, writing activities cover many different genres and should reflect real life situations as closely as possible [12].

The leading role of NA in foreign language learning has remained the focus of many researchers for more than three decades. Thus, D. Nunan views NA as a process of data collection that is vital to identify the skills they need [13]. Although T. Hutchinson \& A. Waters [9] consider learning needs as what a learner has to do to learn, S. Benesch [14] emphasizes that these needs are clearly related to the requirements of the target situation. Researchers from G. Taillefer [15] and D. Cowling [16] presented empirical evidence of the success of English teaching and learning for special purposes on NA. It is clear that NA can help students adapt to the new learning system when their teachers recognize their needs in the learning process [17], [18]. One of the obvious advantages of NA is, first, the recognition of their students, because the NA demonstrates the disadvantages and benefits of the skills that they can use in a potential business or in an academic context. According to $\mathrm{T}$. Iwai et al. NA refers to identifying different types of needs and assessing problems and constraints. Their assumptions included ways in which it was possible to distinguish between the needs identified by analysts and those offered by the respondents themselves [19].

In his article, R. West offered a thorough review of the analysis of foreign language learning needs, including its history, theoretical foundations and approaches to NA. NA 
plays a significant role in training highly qualified specialists capable of achieving the B2 level in foreign language communication competence to the activity through which information is collected, as a basis for developing a curriculum that meets the needs of a particular group of students [20].

In our research we treat NA as an effective instrument of specifying the skills that students can use in potential innovative activities.

This aim has been put on the agenda before the national technical universities which is fully applicable to the National University of Ukraine "Igor Sikorsky Kyiv Polytechnic Institute" (Igor Sikorsky KPI hereafter) being well-known for its scientific and innovative achievements. The status of a research type university raises the requirements for the quality of language training of future graduates, including the aspect of students' research work, in determining the content of which the role of a questionnaire is essential.

We will present and analyze results of two surveys conducted at Igor Sikorsky KPI. The first one was conducted among 220 students of the Institute of Publishing and Printing, the second included 100 respondents of the Faculty of Chemical Engineering and Mechanical Engineering Institute (50 students and 50 teachers). Both surveys despite different specialties are united by one NA aim, namely to specify the ESP writing skills essential for their prospective innovative activities.

\section{Objectives}

The objectives of the research were to focus on the role of NA in learning ESP writing, to identify the students' ESP writing skills essential for their prospective innovative activities. The common objective is specified in the first survey by focusing on the importance of writing in learning ESP, defining students' likes and dislikes in terms of genres and skills of creative writing, while the second survey was aimed at specifying the ESP writing skills essential for research work in the process of diploma design, such as abilities to work with original patent descriptions and produce their own ones. Both surveys were aimed to define the students' needs in terms of language skills and tasks.

\section{Materials and Methods}

NA in ESP writing conduced at Igor Sikorsky KPI used both theoretical and empiric methods. Theoretical methods include study of National ESP Curriculum, ESP syllabi of teaching future publishers and chemical engineers, standards of the field of education for educational level 'Bachelor' with the aim to specify writing skills of level B2.

Our NA also used questionnaire survey as one of empiric methods which are known to be effective tools in researching students' backgrounds, the level of skills, their target needs, teaching methods and techniques. Despite the fact that questioning is not basic but an ancillary method of research, it is able to ensure the mass collection of material through specially designed forms. Researchers acknowledge the fact that the results of the questionnaire are relatively subjective. Therefore, questionnaires are used by methodologists as a supplement to one or another main research method [21].

In order to create quality questionnaires, it is important to note the questions structure, the language and style of their formulation, design, recommendations for questionnaire filling out. One of such recommendations refers to the number of respondents. It is claimed that survey as a research method should involve not less than 100 respondents to get statistically valid results. The validity of the results of our research is provided by the number of respondents.

The first survey involves second, third and fourth year students of the Printing and Publishing Institute. The total number of the respondents constituted 220. The respondents represent such specialties as Publishing and Editing, Journalism, Advertising and Public Relations.

The second survey involves 50 fourth year students and 50 teachers of profile departments of the Faculty of Chemical Engineering and Mechanical Engineering Institute. Both surveys were conducted at Igor Sikorsky KPI and can be characterized as closed (the respondents choose one of the proposed answer); selective (a certain group of participants was involved); written (respondents worked with questionnaire forms). The material of the research is represented by certain types of questionnaires serving different aims. Some of them are aimed at defining the importance of writing in learning ESP. For example such question as Do you think that writing is important in learning English?

Table 1. Do you think that writing is important in learning English?

\begin{tabular}{|c|c|c|c|}
\hline Response & Very important & Important & Not important \\
\hline Participants & 81 & 133 & 6 \\
\hline Percentage & $37 \%$ & $60 \%$ & $3 \%$ \\
\hline
\end{tabular}

Others focus on determining skills essential for creative writing, for example, such skill as formulating an idea.

Table 2. How often do you resort to writing when you need to formulate an idea?

\begin{tabular}{|c|c|c|c|c|}
\hline Response & Almost always & Often & Sometimes & Never \\
\hline Participants & 49 & 105 & 57 & 9 \\
\hline Percentage & $22 \%$ & $48 \%$ & $26 \%$ & $4 \%$ \\
\hline
\end{tabular}

The students and teachers of the Faculty of Chemical Engineering and Mechanical Engineering Institute were asked different questions about the most used means to present the obtained information in a foreign language, also more detailed questions about the kinds of abstracts used in 
their research work. The teachers of profile departments were asked such questions as 'Do your students have to deal with patent documentation in a foreign language in accordance with the educational process?' ('constantly', 'quite often', 'infrequently when necessary', 'never').

It should also be mentioned that the questionnaires began with the introductory part, indicating the purpose of the survey, and recommendations on how to complete it.

\section{Results}

In this section of the study, we will discuss the findings related to the specifying the students' needs in learning writing for specific purposes at Igor Sikorsky KPI. Among NA mechanisms one can mention study of educational qualification characteristics, educational and professional programs and surveys, which are aimed at specifying the professional, scientific, business situations typical or most needed for future specialists as well as the skills necessary for effective communication in the defined situations.

NA conducted at Igor Sikorsky KPI helped in finding the nodes of intersection of professional and foreign language competences clarify the most needed abilities in written specialism oriented communication in English, thus, contributing to determining the content of learning.

The NA included study of requirements of educational and qualification characteristics for the Bachelor level. In the survey conducted in the Printing and Publishing Institute educational and qualification characteristics of such specialties as Publishing and Editing, Journalism, Advertising and Public Relation were studied. The survey conducted at the Faculty of Chemical Engineering and Mechanical Engineering Institute included studying the higher education standard of the field of education 133 (Ukraine) - 'Industrial Engineering' with the presence in the variant part of the educational and qualification characteristics of the educational level 'Bachelor'.

Besides ESP syllabi for related specialties were studied with the aim to find the correspondence (or its absence) with the communication skills described in the educational and qualification characteristics.

Thus, NA conducted at Igor Sikorsky KPI helped to find the nodes of intersection of professional and foreign language competences. For future publishers and editors it was proved to be genre competence.

For future specialists knowledge of the English language is considered as an important component of preparation for professional activity, which involves participation in negotiations, exhibitions and conferences, Future professionals must be able to analyze competitors' works and maintain correspondence and documentation in a foreign language. The necessity of studying different genres of media texts is emphasized, which is an important issue of student's media education development.

The first of two surveys was conducted in the Institute of Printing and Publishing and was focused on the importance of writing in learning English in professional context. The formation of English competence in professionally oriented written communication of future professionals is predetermined by the functions which they will perform in their professional activities, thus, the survey was aimed to specify the students' needs and to investigate the challenges facing the process of teaching future specialists in the publishing industry. Let us examine the findings we obtained from the survey.

When asked about the importance of writing in learning English, 133 respondents (60\%) answered 'important' and $81(37 \%)$ chose 'very important', while only 6 participants (3\%) answered 'not important'. The results seem to be very encouraging as well as the answers to the questions 'How often will you write in English in your future professional activities'. The results show that all the respondents are interested in ESP writing. The majority of them, 115 (52\%) think that English writing is important and some participants $83(38 \%)$ claim that it is very important for professionals, so writing tasks that take into account professional context seem to be very motivating.

Answering the question 'How often do you write in English when you are online' the majority of students (51\% 'often' and 42\% 'sometimes' respectively) write in English when they are online, thus, interactive teacher controlled activities might raise students motivation in doing writing tasks.

A certain set of questions concerns gathering information about writing tasks.

Table 3. What writing tasks do you like doing? And how much?

\begin{tabular}{|c|c|c|c|}
\hline Writing task & Very much & Not Very much & Do not like \\
\hline Essay & $30 \%$ & $50 \%$ & $20 \%$ \\
\hline Translation & $59 \%$ & $29 \%$ & $12 \%$ \\
\hline Notices & $35 \%$ & $51 \%$ & $14 \%$ \\
\hline Instructions & $12 \%$ & $31 \%$ & $57 \%$ \\
\hline Advertisement & $58 \%$ & $32 \%$ & $10 \%$ \\
\hline Letters & $44 \%$ & $45 \%$ & $12 \%$ \\
\hline
\end{tabular}

The students like different writing skills. Some of them (44\%) like writing letters, others like translating (59\%). As for creative writing, advertisements (58\%) take the lead.

Table 4. Do you often write in English when you perform the following tasks?

\begin{tabular}{|c|c|c|c|}
\hline Task & Often & Sometimes & Never \\
\hline Doing research & $11 \%$ & $21 \%$ & $68 \%$ \\
\hline Translation & $69 \%$ & $18 \%$ & $13 \%$ \\
\hline Creating advertisements & $30 \%$ & $35 \%$ & $35 \%$ \\
\hline $\begin{array}{c}\text { Working with business } \\
\text { documents }\end{array}$ & $12 \%$ & $40 \%$ & $48 \%$ \\
\hline Writing reviews & $13 \%$ & $27 \%$ & $60 \%$ \\
\hline
\end{tabular}

As far as we can see once again translation as a written activity dominates. The most confusing is the fact that $68 \%$ of students never write in English while doing research. But the fact that a considerable amount of respondents $(65 \%)$ often or sometimes use English while 
writing advertisements is quite encouraging.

The next set of questions deals with gathering information about writing skills needed in professional communication.

Table 5. In your opinion how often will you use these writing skills in your professional activities?

\begin{tabular}{|c|c|c|c|}
\hline Writing skills & Often & Very often & Never \\
\hline to prepare a presentation & $58 \%$ & $24 \%$ & $18 \%$ \\
\hline $\begin{array}{c}\text { to conduct business } \\
\text { correspondence }\end{array}$ & $63 \%$ & $22 \%$ & $15 \%$ \\
\hline $\begin{array}{c}\text { to take notes while } \\
\text { reading }\end{array}$ & $70 \%$ & $20 \%$ & $10 \%$ \\
\hline to proofread texts & $64 \%$ & $27 \%$ & $9 \%$ \\
\hline $\begin{array}{c}\text { to characterize mass } \\
\text { media products }\end{array}$ & $56 \%$ & $21 \%$ & $23 \%$ \\
\hline $\begin{array}{c}\text { to write advertising } \\
\text { messages }\end{array}$ & $57 \%$ & $28 \%$ & $15 \%$ \\
\hline
\end{tabular}

According to the survey results, the respondents' majority think that different writing skills are useful for their professional activities. We should bear in mind that answers depend on the student's future specialty. Editors rarely make presentations at the same time they might conduct business correspondence and for sure do much proofreading. Nevertheless, there are writing skills that are important for all the specialties, for example, taking notes while reading texts.

As was previously mentioned the objectives of the research were to identify the students' ESP writing skills essential for their prospective creative activities. One of such skills for future specialists in publishing, advertising and public relations is the ability to formulate an idea. When asked 'How often do you resort to writing when you need to formulate an idea?' the majority of participants 105 $(48 \%)$ answered 'often' and 49 (22\%) chose 'almost always'.

Thus, in problem solving activities it seems reasonable to give students some time to formulate their ideas in the written form before expressing them in group discussions.

No doubt defining the difficulties students face performing different writing tasks was one of the objectives of the survey. We present the answers to the question what genre (notice, advertisement, article, review, annotation) is more difficult to produce.

Table 6. Was it difficult to perform written tasks in English?

\begin{tabular}{|c|c|c|c|c|}
\hline & $\begin{array}{c}\text { Very } \\
\text { difficult }\end{array}$ & Difficult & $\begin{array}{c}\text { Not very } \\
\text { difficult }\end{array}$ & Easy \\
\hline Notice & $26 \%$ & $8 \%$ & $19 \%$ & $47 \%$ \\
\hline Advertisement & $39 \%$ & $9 \%$ & $18 \%$ & $34 \%$ \\
\hline Article & $40 \%$ & $3 \%$ & $5 \%$ & $22 \%$ \\
\hline Review & $37 \%$ & $8 \%$ & $8 \%$ & $27 \%$ \\
\hline Annotation & $24 \%$ & $1 \%$ & $0 \%$ & $45 \%$ \\
\hline
\end{tabular}

The results of our empirical study indicate that the respondents find almost the same difficulties in writing notices (34\%), articles (40\%), creating advertisement (48\%) and writing review (45\%). While annotation proved to be the easiest genre to produce. Thus, the necessity to allocate more time to studying different genres of media texts is emphasized, which is an important issue of student's media education development.

Sometimes students' answers are rather contradictive. One set of answers students' answers show that translation is the task the majority of students do most frequently (59\% of the respondents) while more creative task of writing ads is not very popular (only $30 \%$ admitted doing such a task). At the same time answering the question about the most needed writing skills $57 \%$ of the respondents marked the importance of being able to write advertising messages. Thus, the conclusion was made to pay more attention to developing skills in creative writing. Besides, the necessity of studying different genres of media texts is emphasized, which is an important issue of students' media education development.

The second survey which was conducted among 100 respondents (50 fourth year students and 50 teachers of profile departments of the Faculty of Chemical Engineering) was aimed at specifying writing skills students need in the process of their diploma design.

As mentioned above, the strategy of Ukraine's research-type universities is based on the 'Education Science - Innovation' trilogy, which presupposes training specialists capable to meet the challenges of the Fourth Industrial Revolution - Industry 4.0, the technology of which is inseparably tied to the vast amounts of data needed to train artificial intelligence and other key forms of modern technology. The need for data has resulted in exponential growth in gathering it.

According to a European Patent Office study in 2017 there was a $54 \%$ increase in patents filed that were related to Industry 4.0 in the past three years [22]. Increasing role of patent documentation cannot but influence the content of ESP writing.

Besides social needs the content of teaching English in vocational direction is adjusted and detailed on the basis of both state educational standards and educational standards of the respective specialties. Thus, the higher education standard of the field of education 133 (Ukraine) 'Industrial Engineering' with the presence in the variant part of the educational and qualification characteristics of the educational level 'Bachelor', describes bachelor's skills content. Among them we can see the ability to apply knowledge of foreign language in professional communication in the field of chemical and technological, biotechnological, refrigeration, gas and oil refining processes, as well as automation of technological processes. The qualification characteristics also include such skills as using foreign scientific and technical literature, to make annotations, abstracts, documents; applying proper specialism terminology in translating special texts from a foreign language; collecting and analyzing information from foreign electronic sources.

Acquaintance with the specific requirements for the diploma design of all educational and qualification levels, 
which are covered in the educational and methodological literature of the profile departments of the Faculty of Chemical Engineering at Igor Sikorsky KPI, confirmed the presence of the patent search chapter, which proposed an algorithm for processing foreign language patent descriptions. Thus, we have identified the need to model foreign language activities in accordance with the situation of students research work in the process of their diploma design.

In order to determine the need for professionally oriented reading and writing in foreign languages, students of non-language higher educational institutions were interviewed with the ultimate goal of improving methods and techniques for obtaining professional information.

The questionnaire was selective, that is, it involves fourth year students of the Faculty of Chemical Engineering and Mechanical Engineering Institute at Igor Sikorsky KPI. The total number of the respondents constituted 100. The questionnaires consisted of questions of closed and open types, each interviewee worked in writing with the standardized form which contained eight problematic questions. The questionnaire began with the introductory part, indicating the purpose of the survey, and recommendations on how to complete it. The introductory part adjusted the respondents' cooperation for the purpose of obtaining objective answers. Here are some sample questions and analysis of the findings.

The majority of the respondents (86\%) positively answered the question about obtaining new information when reading scientific and technical literature in a foreign language. The answers to the questions where the received information is used show that the majority $(70 \%$ of the respondents) use it in writing course and diploma papers.

In the respondents' opinion abstracts and summaries are the most used means to present the obtained information in a foreign language ( $75 \%$ and $70 \%$ respectively).

Answering more detailed questions about the kinds of abstracts $70 \%$ of the respondents claim the importance of conference material abstracts while $60 \%$ emphasize the significance of writing abstracts to patent documentation.

In order to improve students' training in ESP and to find out the expediency for undergraduates of work with original patent descriptions, we conducted a survey among 50 teachers of profile departments of Igor Sikorsky KPI. The questionnaire contains seven questions.

When asked 'Do your students have to deal with patent documentation in a foreign language in accordance with educational process?' ('constantly', 'quite often', 'infrequently when necessary', 'never'), $73 \%$ of the respondents chose 'infrequently'.

When asked about the purpose of using patent information by students (to prepare for classes in professional disciplines; to determine the technology development level; for diploma design; for writing articles; writing abstracts and reports at student scientific and practical conferences), most $(75 \%)$ of the teachers emphasized the aim to determine the level of development of technology for diploma design and for writing articles.

When asked of the interviewed teachers about their assessment of patent information $80 \%$ assess it as the most expeditious, probable, and specific.

To the question 'Do engineers need to be able to handle foreign patent documentation?' $87 \%$ of the respondents answered positively.

$80 \%$ of the respondents answered the question 'Would a specialized course for teaching foreign patent documentation be useful for your students?'

In response to the question of when it is advisable to introduce training in working with foreign patent descriptions, the majority of those questioned chose the fourth academic year. The results of the survey helped to specify the tasks of foreign language learning in the process of students research work. The main task was formulated as developing students' skills in retrieving and processing patent information to determine the level of the technology development aiming at writing abstracts of their technological modernizations and innovations. We may state that survey as a means of needs analysis contributes to specifying content of teaching written communication in foreign languages.

\section{Discussion}

Recently, questionnaires are gaining importance in all areas of teaching foreign languages. Their role in facilitating learning by providing permanent feedback cannot be overestimated. Moreover, certain issues are highlighted.

First, a questionnaire as a research instrument consisting of a series of questions for the purpose of gathering information can be considered as a kind of written interview. Second, one should understand distinction between open-ended and closed questions, dichotomous ('yes' or 'no'), and polytomous choice among the alternatives) answers. Third, the respondents should understand the terminology used in the questionnaire [23].

NA projects are widely used with the aim to identify the needs of a target group of learners and introduce needs-based course design for developing an ESP language course. Such an approach can be exemplified by ESP language course with a clear focus on the target discipline, accountancy at the Aristotle University of Thessaloniki [24]. The survey used a multi-method approach which involved both quantitative and qualitative research methods to secure its validity and reliability.

In scientific literature, focus on research in needs analysis is either on present situation analysis that can be carried out by means of established placement tests or target situation analysis, which tries to establish what competencies the learners need to develop at the end of the language course, we can't but agree with the idea that 
deficiency analysis helps to integrate present and target situation analysis, always keeping the learning needs in mind [25].

We can't but mention an ambitious task to design an ESP English Writing Course (EWC) at a pre-intermediate level for engineering students studying at English medium departments at a state university in Turkey [26].

The objective of our study is not that ambitious. We did not intend to create separate ESP writing courses. As was previously mentioned the main task of our research was to specify skills in specialism oriented writing needed in creative and innovative professional activities. For future publishers and editors it appeared to be genre competence in writing with focus on such special skill as formulating an idea. Certain improvements to the syllabus "English for students in Publishing and Editing" have been made, more communicative writing tasks have been used in teaching practice. For example such task as 'You are going to write an advertising notice to invite editors to the Advanced Course 'Editor of print and online media'. So far you have got only one sentence. Add the needed information in well formulated reasons for visiting the course'.

As far as specifying the need in ESP writing in the process of students research work writing abstracts to patent information takes the lead. So the tasks of developing students' skills in retrieving and processing patent information as well the task of developing skills in writing abstracts have been included in the "English for students in Chemical Engineering". It should be mentioned that for fourth-year students the aim is specified as writing abstracts of their own technological modernizations and innovations.

Our experience of ESP material development at Igor Sikorsky KPI has proved the importance of NA before developing a course and conducting a survey among students and teachers after its testing.

As far as further prospects of conducting NA in learning ESP at Igor Sikorsky Institute are concerned we intend to use such instruments as semi-structured interviews and questionnaires within data-driven learning (DDL) approach [27]. The main reason for using this approach is the possibility for creation of specialist vocabulary lists and terminological resources.

\section{Conclusions}

Professional training presupposes the creation and use of the integrated competence, which combines knowledge and skills of related disciplines and ESP knowledge and skills.

NA conducted at Igor Sikorsky KPI helped to define the nodes of intersection of professional and foreign language competences. Genre competence was highlighted as a prerequisite for achieving synergistic effect in teaching written communication to students in publishing and editing and retrieving and processing patent information for future chemical and mechanical engineers. Study of ESP syllabi for related specialties showed that writing skills to be used in creative and innovative professional activities need clarifying the role of foreign language in the process of research work, in particular during the diploma design. So questioning students and profile teachers was focused on defining writing skills students might use in the activities mentioned above. The analysis and interpretation of the obtained results enabled the following conclusions.

First, the role of the English language in the process of training specialists with creative and innovative potential should be enhanced by defining target situations for each specialty. According to the results obtained for future specialists in Printing and Publishing they are doing research and writing advertisements, for fourth year students of the Faculty of Chemical Engineering and Mechanical Engineering Institute, it is the situation of diploma design.

Another useful concept was to clarify the most needed skills in written specialism oriented creative activities, As the survey showed for students of Printing and Publishing Institute it is creative writing in different genres while for future mechanical and chemical engineers it is working with foreign patent descriptions as the most expeditious, probable, specific professional information. So in the aspect of multidisciplinary approach to teaching foreign languages, it is necessary to develop the ability to conduct patent search and produce an English-language description of their own development / modernization of the equipment, while it is advisable to organize such activity in the fourth year of the study.

Finally, it is important to note the importance of NA of students in foreign language training, in particular in specifying the content of learning which is determined as a system of scientific knowledge, abilities and skills, mastering of which provides comprehensive development of students' abilities, the formation of their world outlook and preparation for life and work.

\section{REFERENCES}

[1] C. King. Pay as You Learn? Students. In T. Schuller (Ed.), Changing University in The Changing University? Society for Research into Higher Education Ltd., London, 1995.

[2] H. Etzkowitz. Innovation in Innovation: The Triple Helix of university-industry-government relations, Social Science Information, Vol.42, No.3, 293-337.

[3] P. Seedhouse. Needs analysis and the general English classroom, ELT Journal, Vol.49, No.1, 59-65.

[4] C. Chaudron, C. Doughty, Y. Kim, D. Kong, J. Lee, Y. Lee, Y., M. Long, R. Rivers, \& K. Urano. A taskbased needs analysis of a tertiary Korean as a foreign language program. In M. Long. (Ed.), Second language needs analysis. 
Cambridge, Cambridge University. 225-261, 2005.

[5] G. V. Barabanova. Cognitive-Communicative Aspects of Teaching Professionally-Oriented at Non-Linguistic Tertiary School: A Monograph. Simferopol, Tavria. 2003. (Барабанова Г. В. Когнитивно-коммуникативные аспекты обучения профессионально-ориентированного чтению в нязыковом вузе: монографія. Симферополь: Таврия) (in Russian).

[6] R. Yu. Martynova. A comprehensive didactic model of the content of foreign language learning. Kyiv, Vyshcha Shkola. 2004. (Мартинова Р. Ю. Цілісна загальнодидактична модель змісту навчання іноземних мов: монографія) (in Ukrainian).

[7] O. B. Tarnopolsky. Constructivist Blended Learning Approach to Teaching English for Specific Purposes. London, Versita. (2012).

[8] P. C. Robinson. ESP Today: A Practitioner's Guide. Hamel, Hempstead: Prentice Hall, 1991.

[9] T. Hutchinson, A. Waters. English for Specific Purposes: A Learner-Centered Approach. Cambridge, Cambridge University Press, 1987.

[10] T. Dudley-Evans, M. St. John. Developments in ESP: A multi-disciplinary approach. Cambridge, Cambridge University Press , 1998.

[11] N. P. Volkova. Pedagogy: A guide for university students (Pedahohika: Posibnyk dlia studentiv vyshchykh navchalnykh zakladiv). Kyiv, Vydavn. tsentr 'Akademiia', 2003. (in Ukrainian).

[12] C. Tribble. Writing. Oxford, Oxford University Press, 1996.

[13] D. Nunan The Learner-Centred Curriculum. Cambridge, Cambridge University Press, 1988.

[14] S. Benesch. Critical English for Academic Purposes, 2001.

[15] G. Taillefer. The Professional Language Needs of Economic Graduates: Assessment and Perception for French Context. English for Specific Purposes. Vol.26. 135-155.

[16] D. Cowling Needs Analysis: Planning a Syllabus for a Series of Intensive Workplace Courses at a Leading Japanese Company. English for Specific Purposes, 26, 2007.
[17] Chamot, A. Accelerating Academic Achievement of English Language Learners: A Synthesis of Five Evaluations of the CALLA Model. In J. Cummins\& C. Davison (Eds.), International Handbook of English Language Teaching. 85-104.

[18] S. Carkin. English for Academic Purposes. In E. Hinkel (Ed.), Handbook of Research in Second Language Teaching and Learning. Mahwah, NJ, Lawrence Erlbaum, 2005.

[19] T. Iwai, K. Kondo, D.S. J. Lim,, G.E. Ray, H. Shimizu, \& J.D. Brown. Japanese language needs assessment 1998-1999 (NFLRC NetWork \#13). Honolulu, University of Hawai'i, Second Language Teaching \& Curriculum Center. Online available from http://www.nflrc.hawaii.edu/NetWorks/

[20] R. West. Needs analysis in language teaching. Language Teaching, 27/1, 1-19, 1994.

[21] S. Y. Nikolaieva. Methodology of teaching foreign languages in secondary schools: Textbook. (Metodyka navchannia inozemnykh mov u serednikh navchalnykh zakladakh: Pidruchnyk). Kyiv, Lenvit, 2002 (in Ukrainian).

[22] A. Herbert. Industry 4.0: The Fourth Industrial Revolution is Now. Online available from https://towardsdatascience.com/industry-4-0-the-fourt h-industrial-revolution-is-now-38361 fb509da

[23] McLeod S. A. Questionnaire. Online available from https://www.simplypsychology.org/questionnaires.html

[24] D. Chostelidou. A needs analysis approach to ESP syllabus design in Greek tertiary education: a descriptive account of students' needs, Procedia - Social and Behavioral Sciences, Vol.2, No.2, 4507-4512.

[25] M. Haseli Songhori (2008). Introduction to Needs Analysis. English for Specific Purposes World. Issue 4.

[26] B. Tomak, U. Ataş. Designing an ESP Writing Course for Pre-intermediate EFL engineering students, Teaching English for Specific and Academic Purposes, Vol.7, No. 3, 267-282.

[27] S. Smith. DIY Corpora for Accounting \& Finance Vocabulary Learning. English for Specific Purposes, Vol.57, $1-12$. 